\title{
The New Zealand graduated driver licensing system: teenagers' attitudes towards and experiences with this car driver licensing system
}

\author{
Dorothy J Begg, John D Langley, Anthony I Reeder, David J Chalmers
}

\begin{abstract}
Objectives-This study examined the attitudes of teenagers towards the New Zealand graduated driver licensing system (GDLS), and the extent to which it affected them.

Method-Teenagers, who are members of a longitudinal study of a birth cohort, were interviewed at 15 years of age when the GDLS was first introduced and before they had begun licensure, and again at 18 years of age after they had experience with this licensing system.
\end{abstract}

Results-At both ages the majority (over $70 \%$ ) agreed with the driving restrictions imposed by this system. After experience with the restrictions, however, significantly more reported being affected a lot by them, than had expected to be at age 15 . This was especially true of the restrictions on the carrying of passengers and the night time curfew (10 pm-5 am). However, few reported that they were affected by the alcohol restriction. Sixty eight per cent of those with a graduated licence reported breaking at least one of the conditions, most frequently carrying passengers. Very few were penalised by the police for this.

Conclusions-Generally these young drivers were positively disposed towards the driving restrictions, but noncompliance was common. A full evaluation of all aspects of this licensing system is recommended.

(Injury Prevention 1995; 1: 177-181)

Keywords: teenage driving, graduated licensing, attitudes towards licensing, cohort study.

Injury Prevention Research Unit, University of Otago Medical School, PO Box 913, Dunedin, New Zealand DJ Begg JD Langley

AI Reeder

DJ Chalmers

Correspondence to: $\mathrm{Ms}$ Begg young male drivers, have a disproportionately high risk of traffic crash involvement. ${ }^{45}$ Two factors considered to contribute substantially to this high crash risk are youth and inexperience ${ }^{67}$ Driver licensing policies, therefore, usually address these factors. The strategies that have received the most attention are (1) raising the minimum age of licensure so that
In New Zealand as elsewhere, road traffic crash injuries are a leading cause of death and hospitalisation for teenagers. ${ }^{1-3}$ Compared with young drivers are more mature when they begin driving on public roads, and (2) gradually introducing young drivers to driving so that they gain their initial experience under relatively safe conditions. ${ }^{67}$ To reduce the high incidence of young driver traffic crashes in New Zealand, the latter strategy has been adopted.

On 1 August 1987 a graduated driver licensing system (GDLS) was introduced. This was designed to give young drivers (aged 15-24 years inclusive) experience while being excluded from high risk driving situations. ${ }^{6}$ Some of the factors considered to contribute to the high crash risk in young drivers are night time driving, peer pressure and the carrying of passengers, risky driving (including speeding, driving while impaired by alcohol and other drugs, non-use of seat belts), and exposure to risk. ${ }^{8-13}$ Of these factors, three are generally targeted by proponents of graduated licensing: night time driving, driving after drinking alcohol, and the carrying of young passengers. ${ }^{671314}$

Before the introduction of the GDLS in New Zealand a full licence could be obtained at 15 years of age by passing a written, oral, and practical driving test. With the GDLS, full car licensure is now a three stage process: learner licence, restricted licence, full licence. A learner licence can be obtained at age 15 years by passing a written, oral, and eyesight test. With a learner licence the young driver must always be accompanied by a supervisor (that is someone who is 20 years of age or older, has held a full car licence for at least two years, and currently hold a full licence) and they must not drive with more than $30 \mathrm{mg}$ of alcohol $/ 100 \mathrm{ml}$ of blood*. The time period for the learner licence is six months but this can be reduced to three months by gaining a certificate of competency from a recognised driving instructor. A restricted licence, which is acquired by passing a practical driving test, has three main conditions: a night time curfew (10 pm to $5 \mathrm{am}$ ) unless accompanied by a supervisor (as for learner licence); no carrying of passengers unless accompanied by a supervisor; and an alcohol restriction (as for the learner licence). A

*In 1993 the alcohol limit of $30 \mathrm{mg} / 100 \mathrm{ml}$ of blood or $150 \mu \mathrm{g} / 1$ of breath was extended to include all teenage drivers, irrespective of licence status. Penalties, other than extensions to the learner licence and restricted licence periods, for violations of this limit were also introduced. 
restricted licence may be held for 18 months, although this can be reduced to nine months by completing a defensive driving course or an advanced driving course. Once the restricted licence stage has been completed a full licence can be obtained. Under the GDLS, therefore, a driver can be fully licensed after two years but with formal driving instruction this can be reduced to one year. Violations of the GDLS conditions can be penalised only by extensions of up to six months to the relevant licence period.

New Zealand was the first country to introduce a comprehensive graduated licensing system. Other regions, such as Victoria in Australia, have introduced similar schemes, and several others have indicated an interest in following suit. ${ }^{13}$ Despite the evidence that graduated licensing has had a beneficial effect on the number of injuries sustained by young drivers in New Zealand ${ }^{13}$ there is some resistance to introducing such schemes. One barrier is the assumption that young people will be opposed to such restrictions. ${ }^{15}$ Little is known, however, about the attitudes of teenagers to driving restrictions and especially of teenagers who have had experience with them. Two studies, one conducted in the United States and one in New Zealand, have reported that young people were not strongly committed either for or against driving restrictions. ${ }^{15}{ }^{16}$ The majority of the teenagers involved in these studies, however, had not had any actual experience with driving restrictions. The main aim of the present study was to assess the attitudes of teenagers to driving restrictions, based on the experiences of a cohort of young New Zealanders, who were among the first drivers to be licensed under the graduated licensing system.

We examined attitudes to graduated licensing both before and after experience with the licensing system. We also investigated the extent to which the driving restrictions had affected these young people, and the aspects of their lives that had been affected by them. Finally we were interested to establish whether the young drivers had complied with the driving restrictions.

\section{Methods}

THE COHORT

This project was undertaken as part of a longitudinal study, the Dunedin Multidisciplinary Health and Development Study (DMHDS). The DMHDS has examined the health, development, attitudes, and behaviour of a cohort born at the only obstetric hospital in Dunedin, New Zealand between 1 April 1972 and 31 March 1973. At age 3 years, of the 1139 eligible for inclusion, $1037(91 \%)$ were followed up and assessed. Further assessments have been conducted at intervals of two years through to age 15 years, then again at 18 and 21 years of age. A full description of the cohort and the study has been provided by Silva. ${ }^{17}$

At 15 years of age, $976(95 \%)$ of the 1029 surviving teenagers were assessed. Of these, 852 attended the research unit for a full day of assessments $\dagger$. The 848 who completed the injury assessment were included in the age 15 section of this study. Consent for participation was obtained from both the cohort member and a parent. At 18 years, $993(97 \%)$ of the surviving teenagers were assessed, and $879(86 \%)$ attended the research unit for full assessments. Of these, 876 completed the injury assessment and were eligible to be included in the age 18 section of this study. Consent for participation was obtained only from the cohort member.

\section{SOURCES OF INFORMATION}

Injury research has been one of the major components of the DMHDS. At ages 15 and 18 the injury assessment consisted of structured questionnaires administered in face-to-face interviews by trained interviewers. The main focus of these interviews was road traffic safety issues, including questions relating to the GDLS.

The data collection stage of the age 15 assessment began in March 1987 and continued until May 1988. The GDLS legislation was introduced on 1 August 1987. To ensure that cohort members were aware of the conditions of the GDLS, the questions in the age 15 questionnaire were preceded by a brief statement that explained these restrictions. For example, the question relating to the learner licence was: 'A Learner's permit is for 6 months. During this time you must be accompanied at all times by a driver who is at least 20 years of age, has held a full licence for 2 years, and who is in charge. How will that affect you?' The response options were: 'not at all', 'a little', 'a lot', 'not sure'. If the response was 'a lot' further details regarding the reason were sought. The procedure for all the questions was similar to this, except that where appropriate the choice of responses was 'strongly agree', 'agree', 'disagree', 'strongly disagree'. At age 18 , the GDLS questions and the procedures followed were similar to age 15 , except that there was no explanatory statement about the restrictions, and the tense of the questions made allowance for the licence status of the cohort member. (Copies of the age 15 and age 18 questionnaires are available, on request, from the first author.)

The response options 'not at all' and 'a little' were considered similar and were grouped for the analysis, as were 'strongly agree' and 'agree', and 'strongly disagree' and 'disagree'. McNemar's test for paired samples was used for the comparison of the age 15 and age 18 results. ${ }^{18}$

\section{Results}

AGE 15

Of the 84815 year olds who were given the questionnaire, 23 were excluded (one was no longer resident in New Zealand and 22 already held a driver's licence). There were no significant differences in the responses given by those interviewed before the introduction of

†A full assessment consisted of a full day of interviews including assessments for each of the following: injury, mental health, antisocial behaviour, tobacco use, alcohol use, respiratory function, and sexual behaviour. 
the GDLS $(34 \%)$ and those interviewed after $(66 \%)$, so these responses were combined for the subsequent analysis. Table 1 presents the responses given at age 15 , for those who had not commenced licensure, and shows that the majority did not expect that any of the restrictions would greatly affect them. Also, a substantial majority agreed with the restrictions. There were no significant differences by sex. For those who expected that the driving restrictions would affect them a lot, the reasons given were classified as: inconvenience to

Table 1 Expected effect of the conditions of the GDLS and attitude towards the restrictions at age 15 - before commencing licensure; figures are number $(\%)$

\begin{tabular}{|c|c|c|c|c|}
\hline & Males $\star$ & Females ${ }^{\star}$ & $\chi^{2}$ & $p$ Value \\
\hline $\begin{array}{l}\text { Learner's licence } \\
\text { A little/not at all } \\
\text { A lot }\end{array}$ & $\begin{array}{l}262(62) \\
125(30)\end{array}$ & $\begin{array}{l}256(64) \\
109(27)\end{array}$ & 0.5 & 0.5 \\
\hline $\begin{array}{l}\text { Restricted licence co } \\
\text { (A) Night time curf } \\
\text { A little/not at all } \\
\text { A lot }\end{array}$ & $\begin{array}{l}\text { ditions } \\
\begin{array}{r}347(82) \\
60(14)\end{array}\end{array}$ & $\begin{array}{r}333(83) \\
45(11)\end{array}$ & $1 \cdot 4$ & 0.2 \\
\hline $\begin{array}{l}\text { (B) Passenger restri } \\
\text { A little/not at all } \\
\text { A lot }\end{array}$ & $\begin{array}{l}\text { ion } \\
288(68) \\
112(27)\end{array}$ & $\begin{array}{l}262(65) \\
112(28)\end{array}$ & 0.4 & 0.6 \\
\hline $\begin{array}{l}\text { (C) Alcohol restricti } \\
\text { A little/not at all } \\
\text { A lot }\end{array}$ & $\begin{array}{l}397(94) \\
11(3)\end{array}$ & $\begin{array}{r}382(95) \\
7(2)\end{array}$ & 0.7 & 0.4 \\
\hline $\begin{array}{l}\text { Overall agree/disagr } \\
\text { Agree } \\
\text { Disagree }\end{array}$ & $\begin{array}{l}\text { with the } \\
331(78) \\
88(21)\end{array}$ & $\begin{array}{r}\text { strictions } \\
324(80) \\
74(18)\end{array}$ & 0.7 & 0.4 \\
\hline
\end{tabular}

*Totals do not equal $100 \%$ as 'other' responses have been excluded from the table. 'Other' responses include not sure, not applicable, or missing data.

Table 2 Extent affected by the conditions of the GDLS and attitude towards the restrictions at age $18-$ graduated licensed drivers only; figures are number $(\%)$

Males ${ }^{\star}$ Females $\chi^{2} \quad$ p Value

\begin{tabular}{|c|c|c|c|c|}
\hline $\begin{array}{l}\text { Learner's licence } \\
\text { A little/not at all } \\
\text { A lot }\end{array}$ & $\begin{array}{r}204(64) \\
96(30)\end{array}$ & $\begin{array}{r}191(77) \\
51(21)\end{array}$ & $8 \cdot 1$ & 0.004 \\
\hline \multicolumn{5}{|c|}{$\begin{array}{l}\text { Restricted licence conditions } \\
\text { (A) Night time curfew }\end{array}$} \\
\hline $\begin{array}{l}\text { (B) Passenger restric } \\
\text { A little/not at all } \\
\text { A lot }\end{array}$ & $\begin{array}{l}\text { ion } \\
182(57) \\
121(38)\end{array}$ & $\begin{array}{l}122(49) \\
121(49)\end{array}$ & $5 \cdot 3$ & 0.02 \\
\hline $\begin{array}{l}\text { (C) Alcohol restricti } \\
\text { A little/not at all } \\
\text { A lot }\end{array}$ & $\begin{array}{l}288(91) \\
18(6)\end{array}$ & $\begin{array}{c}233(94) \\
12(5)\end{array}$ & 0.3 & 0.6 \\
\hline $\begin{array}{l}\text { Overall agree/disagr } \\
\text { Agree } \\
\text { Disagree }\end{array}$ & $\begin{array}{l}\text { with the } \\
215(68) \\
91(29)\end{array}$ & $\begin{array}{r}\text { strictions } \\
181(73) \\
64(26)\end{array}$ & 0.8 & 0.35 \\
\hline
\end{tabular}

*'Totals do not equal $100 \%$ as 'other' responses have been excluded from the table. 'Other' responses include not sure, not applicable, or missing data.

Table 3 Reasons given for having been affected a lot by the driving restrictions graduated licensed drivers only at age 18 ; figures are number $(\%)$

\begin{tabular}{lcccc}
\hline Reasons given & $\begin{array}{l}\text { Learner } \\
\text { licence }\end{array}$ & $\begin{array}{l}\text { Night time } \\
\text { curfew }\end{array}$ & $\begin{array}{l}\text { Passenger } \\
\text { restriction }\end{array}$ & $\begin{array}{l}\text { Alcohol } \\
\text { restriction }\end{array}$ \\
\hline Inconvenience to parents or other persons & $45(31)$ & $7(4)$ & $35(14)$ & 0 \\
$\quad$ 20 years of age or older & $12(8)$ & $98(52)$ & $63(26)$ & $12(40)$ \\
Restriction on social activities & $49(33)$ & $40(21)$ & $79(33)$ & $8(27)$ \\
General limitation on mobility & $2(1)$ & $4(2)$ & $4(2)$ & 0 \\
Restriction on sporting activities & $8(5)$ & $16(8)$ & $3(1)$ & 0 \\
Restriction on work related activity & $9(6)$ & $15(8)$ & $20(8)$ & 0 \\
$\begin{array}{l}\text { Several activities restricted (for example } \\
\text { sport and work/sport and social) }\end{array}$ & $22(15)$ & $10(5)$ & $38(16)$ & $10(33)$ \\
Other & $147(99)$ & $190(100)$ & $242(100)$ & $30(100)$ \\
Total & & & &
\end{tabular}

^Percentage totals do not all equal 100 due to rounding. family and other persons over 20 years of age $(40 \%)$, restriction on social activities $(20 \%)$, general limitation on mobility $(15 \%)$, restriction on travel for sports activity $(5 \%)$, and restriction on travel for work $(4 \%)$.

AGE 18

At age 18, of the 876 cohort members interviewed, $567(65 \%)$ held some form of graduated licence: $271(46 \%)$ a full graduated licence, $197(34 \%)$ a restricted licence, 99 $(17 \%)$ a learner licence. The remainder either had no licence or held another type of licence. Only the 567 who held a graduated licence were asked the questions relating to experience with the new driving restrictions. The responses given to questions relating to the effect of the conditions of the GDLS are presented in table 2. Except for the passenger restriction (for females only), the majority reported that they had not been affected a lot by the restrictions. There were differences, however, by gender with more males than females being affected a lot by the learner licence $(p=0.004)$ but more females than males being similarly affected by the night time curfew $(p=0.005)$ and the passenger restriction $(p=0.020)$. There was no gender difference with respect to the alcohol restriction nor with the proportion who agreed with the GDLS. For those who reported that the driving restrictions had affected them a lot, the reasons given were quite similar to those given at age 15, and are summarised in table 3. The reasons given by males and females did not differ significantly.

COMPARISON OF RESPONSES GIVEN BEFORE (AGE 15) AND AFTER (AGE 18) LICENSURE

The purpose of this comparison was to establish whether there was a difference between how these teenagers expected to be affected by the new driving restrictions (before licensure), how they had actually been affected by them (after licensure commenced), and whether their attitude towards the driving restrictions had changed. Only those who held a graduated licence at age 18 were included in this analysis, and because of gender differences at age 18, these results are presented separately for males and females. Using McNemar's test for comparison of proportions in paired samples, ${ }^{18}$ the responses given at age 15 were compared with the responses given at age 18 . These results are summarised in table 4.

From age 15 to age 18 there was no significant change with regard to the effect of the learner licence, although fewer females found they had been seriously affected by it at age 18, than expected to be at age 15 . For the conditions of the restricted licence there was a significant increase in the proportion who were affected a lot at age 18, compared with those whose expected to be affected at age 15 . These differences applied to all of the conditions of the restricted licence, although the proportions affected by the alcohol restriction at both ages 15 and 18 were quite small. At age 18 there was a significant decrease in the proportion who agreed with the driving restrictions, for both males and females. 
Table 4 A comparison of the responses given at age 15 (before commencing licensure) and at age 18 (after experience with the graduated licensing system) by gender

\begin{tabular}{|c|c|c|c|c|c|c|c|c|}
\hline \multirow[b]{2}{*}{$\begin{array}{l}\text { Extent } \\
\text { affected by }\end{array}$} & \multicolumn{4}{|l|}{ Males } & \multicolumn{4}{|l|}{ Females } \\
\hline & $\begin{array}{c}\text { Age } 15 \\
\left(\begin{array}{c}0 \\
o\end{array}\right)\end{array}$ & $\begin{array}{l}\text { Age } 18 \\
(\%)\end{array}$ & $\chi^{2}+$ & $\stackrel{p}{\text { Value }}$ & $\begin{array}{l}\text { Age 15 } \\
(\%)\end{array}$ & $\begin{array}{l}\text { Age } 18 \\
(\%)\end{array}$ & $\chi^{2}+$ & $\stackrel{p}{\text { Value }}$ \\
\hline $\begin{array}{l}\text { Learner's licence } \\
\text { A little/not at all } \\
\text { A lot }\end{array}$ & $\begin{array}{l}62 \\
30\end{array}$ & $\begin{array}{l}64 \\
30\end{array}$ & $1 \cdot 0$ & 0.3 & $\begin{array}{l}64 \\
27\end{array}$ & $\begin{array}{l}77 \\
21\end{array}$ & $3 \cdot 2$ & 0.07 \\
\hline $\begin{array}{l}\text { Restricted licence } \\
\text { (A) Night time curfew } \\
\text { A little/not at all } \\
\text { A lot }\end{array}$ & $\begin{array}{l}82 \\
14\end{array}$ & $\begin{array}{l}68 \\
28\end{array}$ & $20 \cdot 6$ & 0.001 & $\begin{array}{l}83 \\
11\end{array}$ & $\begin{array}{l}58 \\
40\end{array}$ & $64 \cdot 1$ & 0.001 \\
\hline $\begin{array}{l}\text { (B) Passenger restriction } \\
\text { A little/not at all } \\
\text { A lot }\end{array}$ & $\begin{array}{l}68 \\
27\end{array}$ & $\begin{array}{l}57 \\
38\end{array}$ & $10 \cdot 4$ & 0.001 & $\begin{array}{l}65 \\
28\end{array}$ & $\begin{array}{l}49 \\
49\end{array}$ & $18 \cdot 8$ & 0.001 \\
\hline $\begin{array}{l}\text { (C) Alcohol restriction } \\
\text { A little/not at all } \\
\text { A lot }\end{array}$ & $\begin{array}{r}94 \\
3\end{array}$ & $\begin{array}{r}91 \\
6\end{array}$ & $4 \cdot 3$ & 0.04 & $\begin{array}{r}95 \\
2\end{array}$ & $\begin{array}{r}94 \\
5\end{array}$ & $7 \cdot 6$ & 0.006 \\
\hline $\begin{array}{l}\text { Overall agree/disagree wi } \\
\text { Agree } \\
\text { Disagree }\end{array}$ & $\begin{array}{l}h \text { the res } \\
78 \\
21\end{array}$ & $\begin{array}{l}\text { rictions } \\
68 \\
29\end{array}$ & $8 \cdot 7$ & 0.003 & $\begin{array}{l}80 \\
18\end{array}$ & $\begin{array}{l}73 \\
26\end{array}$ & $3 \cdot 7$ & 0.05 \\
\hline
\end{tabular}

^Totals do not equal $100 \%$ as 'other' responses have been excluded from the table. 'Other' responses include not sure, not applicable, or missing data. $\nmid \mathrm{McNemar}$ 's test for paired data.

Table 5 Compliance with the conditions of the graduated driver licence (GDL), by licence status, and the extent of enforcement by the police; figures are number $(\%)$

\begin{tabular}{|c|c|c|c|c|}
\hline & Learner licence & $\begin{array}{l}\text { Restricted } \\
\text { licence }\end{array}$ & $\begin{array}{l}\text { Full graduated } \\
\text { licence }\end{array}$ & Total \\
\hline $\begin{array}{l}\text { 'Have you broken [did you break } \\
\text { Yes } \\
\text { No } \\
\text { Other` } \\
\text { Total } \dagger\end{array}$ & $\begin{array}{l}\text { any of the con } \\
38(38) \\
60(61) \\
1(1) \\
99(100)\end{array}$ & $\begin{array}{l}\text { ditions of th } \\
149(76) \\
47(24) \\
1(1) \\
197(100)\end{array}$ & $\begin{array}{l}\text { GDL?' } \\
196(72) \\
71(26) \\
4(1) \\
271(100)\end{array}$ & $\begin{array}{l}383(68) \\
178(31) \\
6(1) \\
567(100)\end{array}$ \\
\hline $\begin{array}{l}\text { Conditions broken } \\
\text { Accompanied only } \\
\text { Passenger only } \\
\text { Night only } \\
\text { Alcohol only } \\
\text { Passenger and night } \\
\text { Passenger, night, and alcohol } \\
\text { Other }{ }^{\star} \\
\text { Total } \dagger\end{array}$ & $\begin{array}{l}16(42) \\
7(18) \\
1(3) \\
0 \\
4(11) \\
5(13) \\
5(13) \\
38(100)\end{array}$ & $\begin{array}{c}3(2) \\
44(30) \\
6(4) \\
0 \\
69(46) \\
24(16) \\
3(2) \\
149(100)\end{array}$ & $\begin{aligned} & 1(1) \\
& 90(46) \\
& 10(5) \\
& 1(1) \\
& 83(42) \\
& 8(4) \\
& 3(2) \\
& 196(100)\end{aligned}$ & $\begin{aligned} & 20(5) \\
& 141(37) \\
& 17(4) \\
& 1(0) \\
& 156(41) \\
& 37(10) \\
& 11(3) \\
& 383(100)\end{aligned}$ \\
\hline $\begin{array}{l}\text { 'Were you caught by the police?' } \\
\text { Yes } \\
\text { No } \\
\text { Other }{ }^{\star} \\
\text { Total } \dagger\end{array}$ & $\begin{array}{l}12(32) \\
24(63) \\
2(5) \\
38(100)\end{array}$ & $\begin{aligned} 28(19) \\
120(81) \\
1(1) \\
149(100)\end{aligned}$ & $\begin{array}{c}28(14) \\
168(86) \\
0 \\
196(100)\end{array}$ & $\begin{aligned} 68 & (18) \\
312 & (81) \\
3 & (1) \\
383 & (100)\end{aligned}$ \\
\hline $\begin{array}{l}\text { 'Were you penalised?' } \\
\text { Yes } \\
\text { No } \\
\text { Other` } \\
\text { Total } \dagger\end{array}$ & $\begin{array}{c}6(50) \\
4(33) \\
2(17) \\
12(100)\end{array}$ & $\begin{array}{c}16(57) \\
9(32) \\
3(11) \\
28(100)\end{array}$ & $\begin{array}{l}12(43) \\
16(57) \\
0 \\
28(100)\end{array}$ & $\begin{array}{c}34(50) \\
29(43) \\
5(7) \\
68(100)\end{array}$ \\
\hline
\end{tabular}

${ }^{\star}$ Includes other and unspecified. †Percentage totals do not always equal 100 due to rounding.

COMPLIANCE WITH AND ENFORCEMENT OF THE GDLS

Among those who held a learner licence, males were more likely than females to have broken the conditions of their licence $(46 \%$ of the males compared with $30 \%$ of the females) but for those with a restricted or a full graduated licence there was little difference by gender, both for the proportion who broke the conditions, and the conditions which they had broken. These results are presented in table 5 and show that, for the whole group, $68 \%$ had broken at least one condition of their licence. This proportion varied from $38 \%$ of those with a learner licence to $76 \%$ of those with a restricted licence and $72 \%$ of those with a full graduated licence. The passenger restriction and night time curfew were the conditions most frequently broken, although the night time curfew alone was broken in only $4 \%$ of the cases. Table 5 also shows that of those who broke the conditions of the licence, $18 \%$ were apprehended by the police. Of these, half had the period of the relevant licence extended.

\section{Discussion}

One of the key factors influencing the effectiveness of a graduated licensing system is the attitude of the drivers towards it, and their willingness to comply with the restrictions. The results from this study showed that the majority of the teenagers were in general agreement with the driving restrictions, and, despite a significant decrease in this support after experience with the licensing process, they still provided stronger support for such restrictions than has been previously demonstrated. ${ }^{1516}$ However, over two thirds reported that they had broken at least one condition of their graduated licence. Of those with a full graduated or restricted licence, $92 \%$ had broken the restriction on carrying passengers and $60 \%$ the night time curfew. Unfortunately when we conducted this study we did not anticipate such a high level of non-compliance and did not inquire about how repeatedly the restrictions were broken. The high level of non-compliance in our study, however, confirms the findings of another survey that reported that for some individuals these violations of the conditions were very frequent with about $33 \%$ breaking the passenger restriction and $17 \%$ the night time curfew, on at least a weekly basis. ${ }^{19}$ For at least some of the drivers in our study, therefore, the violations reported were probably not isolated incidents.

Given the high profile of young males in the road traffic statistics ${ }^{12}$ it was somewhat surprising to find that, after experience with these restrictions, more females than males reported being affected a lot by the night time curfew and passenger restrictions. There was little evidence, however, that the restrictions had caused any real practical difficulties, such as travel to school or work, for either the males or females, as both reported social activities or general mobility as the main types of activity affected. However, the majority of the members of this cohort were from an urban area, and their experiences may not necessarily reflect those from rural areas in New Zealand.

An earlier report suggested that young drivers did not have a high expectation of being apprehended by the police if they violated the conditions of the GDLS. ${ }^{16}$ Our results show that this expectation was not unfounded. Only $18 \%$ of those who broke licence conditions were apprehended by the police, and only half were penalised. Furthermore, if they were apprehended the only penalty that could have been imposed was an extension to the relevant licence, which was of little consequence to a young driver who blatantly disregarded the restrictions.

Despite the evidence of widespread noncompliance and a low level of official enforcement, the GDLS does appear to have had a positive impact on the number of young drivers being injured on the road. Road traffic casualty statistics show a reduction in the number of young driver (15-19 years olds) crashes since the GDLS was introduced, and also the young 
driver crashes as a proportion of all crashes has decreased. ${ }^{19} \mathrm{~A}$ recent nationwide study showed an estimated $23 \%$ reduction in the trend in hospital admissions for motor vehicle occupants in the 15-19 year age group, following the GDLS, which compared with a $16 \%$ reduction for the 25 plus age group, and $12 \%$ reduction for the 20-24 year age group. ${ }^{20} \mathrm{~A}$ reduction in the number of young drivers on the road was the main reason for the greater reduction in traffic related injury to $15-19$ year olds.

\section{Conclusion - implications for prevention}

The present study shows that the attitude of teenagers to the GDLS was generally favourable. Furthermore, for the young people who were most affected by the restrictions it was largely discretionary travel that was involved. There is good evidence that the number of young people injured on our roads has decreased since the graduated licensing was introduced. It seems, therefore, that graduated licensing is an acceptable and effective method of reducing road traffic injuries to young people. The relative contribution of the specific conditions of the GDLS to this reduction has yet to be established. At present, the only study that has addressed this issue was based on traffic crashes reported to the police, which represent only $50 \%$ of all injury crashes. ${ }^{19}$ There is evidence that the GDLS has resulted in a delay in the age of licensure thus reducing the number of young drivers on the road, and that this is the main factor contributing to the reduction in crash injuries. ${ }^{1920} \mathrm{~A}$ comprehensive evaluation of all aspects of this licensing system is needed to determine how its effectiveness can be further improved.

The Dunedin Multidisciplinary Health and Development Study (DMHDS) is funded by the Health Research Council of New Zealand. The Injury Prevention Research Unit (IPRU) is funded jointly by the Health Research Council of New Zealand and the Accident Rehabilitation and Compensation Insurance Corporation (ACC) of New Zealand. At the time of writing the first author held an ACC Overseas Fellowship. The authors wish to acknowledge the support of Mrs Julie Cecchi, Ms Judy Clarke, Ms Maree Drury and Dr Anna Waller for their contribution to this study, and Mr Bill Frith and Dr Narelle Haworth for their comments on an earlier version of this paper. The authors also, wish to acknowledge the contribution of $\mathrm{Mr}$ Stephen Marshall for his assistance with the statistical analyses, Stephen Marshall for his assistance with the statistical analyses,
and Dr Phil Silva, Director of the DMHDS, for his ongoing and Dr Phil Silva, Director of the DMHDS, for his ongoing support. We would also like to thank the members of the
DMHDS cohort whose cooperation made this study possible.

1 New Zealand Health Information Service. Mortality and demographic data 1991. Wellington, New Zealand: Ministry of Health, 1993.

2 New Zealand Health Information Service. Hospital and selected morbidity data 1992. Wellington, New Zealand: Ministry of Health, 1993.

3 Baker SP, O’Neill B, Ginsburg MJ, Guohoa L. The injury fact book. 2nd Ed. New York: Oxord University Press, 1992.

4 Karpf RS, Williams AF. Teenage drivers and motor vehicle deaths. Accid Anal Prev 1983; 15: 55-63.

5 Bailey JPM. A study of road accident victims in New Zealand aged 13 to 18. (ACC Research Report Number 104.) Petone, New Zealand: Accident Compensation Corporation, 1988.

6 Ministry of Transport. A graduated driver licensing system. Wellington, New Zealand: Office of the Ministry of Transport, July 1985

7 Waller PF. Graduated licensing: Rx for motor vehicle injury prevention. Symposium on driver improvement: planning for the $90 \mathrm{~s}$. Sidney, British Columbia. Ottawa: Traffic Injury Research Foundation of Canada, 1990.

8 Robertson LS. Patterns of teenaged driver involvement in fatal motor vehicle crashes. Implications for policy choice. F Health Polit Policy Law 1981; 6: 303-14.

9 Williams AF. Fatal motor vehicle crashes involving teenagers. Pediatrician 1983-85; 12: 37-40.

10 Williams AF. Night-time driving and fatal crash involvement of teenagers. Accid Anal Prev 1985; 17: 1-5.

11 Rolls GW, Hall RD, Ingham R, McDonald M. Accident risk and behavioural patterns of younger drivers. Southampton, and behavioural patterns of younger drivers. Southampton

12 Jonah BA. Accident risk and risk-taking behaviour among young drivers. Accid Anal Prev 1986; 18: 255-71.

13 Traffic Injury Research Foundation of Canada. New to the road. Prevention measures for young or novice drivers. Key findings and implications from an international symposium, February 1991, Halifax Nova Scotia. Ottawa: Traffic Injury Research Foundation of Canada.

14 Boughton CJ, Carrick C, Noonan G. Development of graduated licensing in Australia. In: Benjamin T, ed.
. Young drivers impaired by alcohol and other drugs. International congress and symposium series No 116. London Royal Society of Medicine Services, 1987.

15 Williams AF, Preusser DF, Lund AK. High schoo students' views of laws restricting teenage driving. $f$ Public Health Policy 1984; 5: 387-95.

16 Whines JR. Young people and driving: the graduated driver licensing system. National road safety seminar. Wellington, New Zealand. Seminar papers 1988: 325-45.

17 Silva PA. The Dunedin Multidisciplinary Health and Development Study: a fifteen year longitudinal study. Perinatal and Paediatric Epidemiology 1990; 4: 76-107.

18 Snedecor GW, Cochran WG. Statistical methods, 7th Ed. Ames, Iowa: The Iowa State University Press, 1980.

19 Frith WJ, Perkins WA. The New Zealand graduated driver licensing system. National road safety seminar. Welling ton, New Zealand. Seminar papers 2 1992: 256-78

20 Langley JD, Wagenaar A, Begg DJ. An evaluation of the New Zealand graduated driver licencing system. Accid Anal Prev (in press).

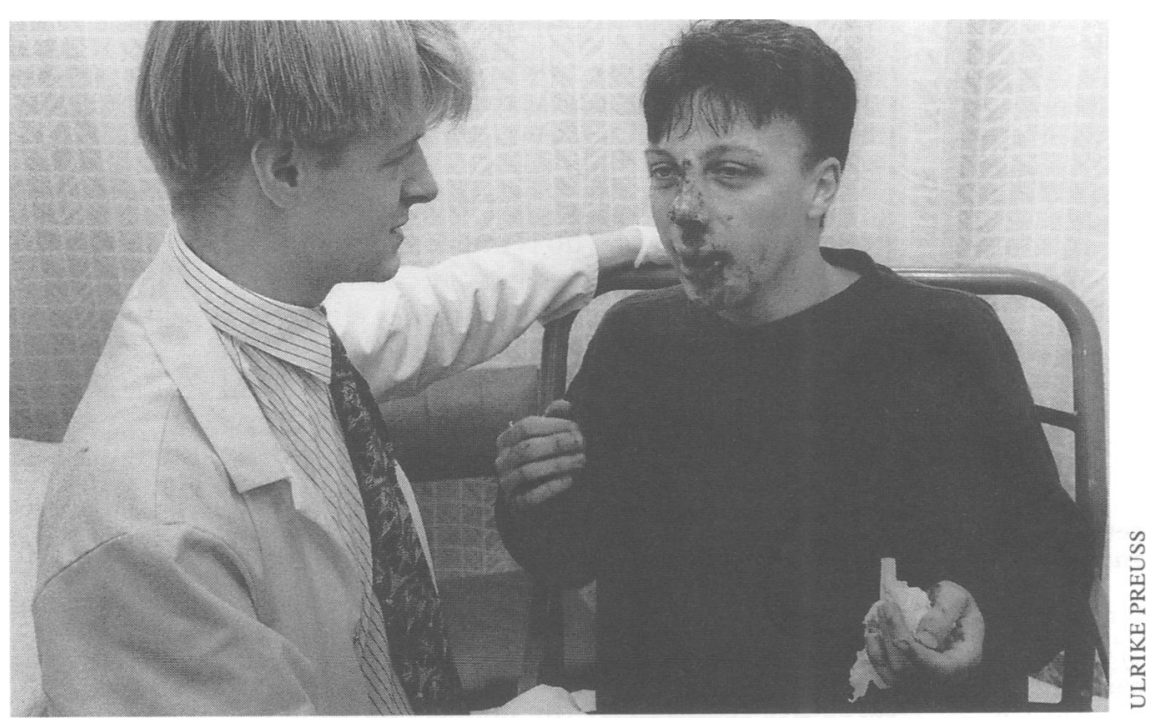

